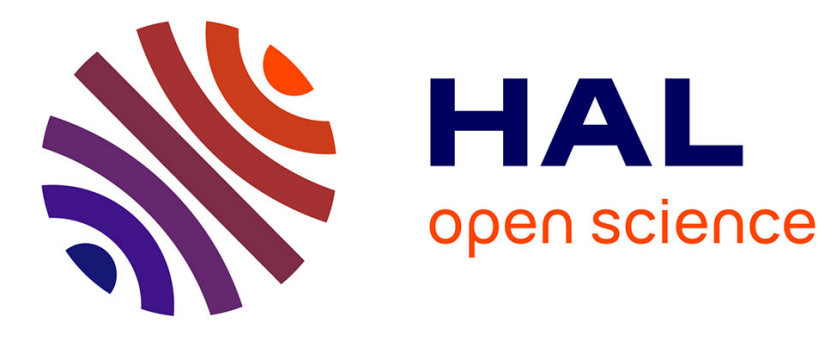

\title{
Organometallic-Mediated Radical Polymerization of Vinylidene Fluoride
}

\author{
Sanjib Banerjee, Vincent Ladmiral, Antoine Debuigne, Christophe \\ Detrembleur, Rinaldo Poli, Bruno Ameduri
}

\section{To cite this version:}

Sanjib Banerjee, Vincent Ladmiral, Antoine Debuigne, Christophe Detrembleur, Rinaldo Poli, et al.. Organometallic-Mediated Radical Polymerization of Vinylidene Fluoride. Angewandte Chemie International Edition, 2018, 57, pp.2934-2937. 10.1002/anie.201712347 . hal-01725498

\section{HAL Id: hal-01725498 \\ https://hal.science/hal-01725498}

Submitted on 1 Mar 2021

HAL is a multi-disciplinary open access archive for the deposit and dissemination of scientific research documents, whether they are published or not. The documents may come from teaching and research institutions in France or abroad, or from public or private research centers.
L'archive ouverte pluridisciplinaire HAL, est destinée au dépôt et à la diffusion de documents scientifiques de niveau recherche, publiés ou non, émanant des établissements d'enseignement et de recherche français ou étrangers, des laboratoires publics ou privés. 


\title{
Organometallic Mediated Radical Polymerization of Vinylidene
}

\section{Fluoride}

\author{
Sanjib Banerjee, ${ }^{[a], \#}$ Vincent Ladmiral, ${ }^{[a]}$ Antoine Debuigne, ${ }^{[b]}$ Christophe Detrembleur, ${ }^{[b]}$ Rinaldo \\ Poli*,[c],[d] and Bruno Améduri*,[a]
}

\begin{abstract}
An unprecedented level of control for the radical polymerization of vinylidene fluoride (VDF), yielding well-defined PVDF (up to $14,500 \mathrm{~g} / \mathrm{mol}$ ) with low dispersity ( $\leq 1.32$ ), was achieved using organometallic mediated radical polymerization (OMRP) with an organocobalt compound as initiator. The high chain-end fidelity was demonstrated by the synthesis of PVDF- and PVAc-containing di-and tri-block copolymers. DFT calculations rationalize the efficient reactivation of both head and tail chain end dormant species.
\end{abstract}

Poly(vinylidene fluoride), PVDF, is the second largest commercially available fluoropolymer after polytetrafluoroethylene (PTFE). It exhibits remarkable properties such as hydrophobic and oleophobic properties, chemical resistance to acids and solvents, low dielectric constants and excellent weathering. ${ }^{[1]}$ Hence, it finds uses in many high-tech applications in aerospace and aeronautical engineering, coatings, ${ }^{[1 \mathrm{~d}]}$ piezo/ferroelectric devices, ${ }^{[2]}$ backsheets for photovoltaic devices and functional membranes for water treatment. ${ }^{[3]}$ VDF has a reactivity close to those of $\mathrm{TFE}^{[1 \mathrm{~b}]}$ and chlorotrifuoroethylene, ${ }^{[4]}$ but it is not explosive and much less toxic. ${ }^{[1 c]}$

Reversible deactivation radical polymerization (RDRP) of VDF has only been achieved using two techniques: (i) iodine transfer polymerization (ITP), ${ }^{[1 c,}$ 5] and (ii) reversible addition fragmentation chain transfer (RAFT) polymerization. ${ }^{[6]}$ Both techniques require the use of a radical initiator and a suitable chain transfer agent (CTA), which ensures the reversible degenerative transfer (DT) at the heart of ITP and RAFT. Both were shown to produce relatively well-defined diblock $\left.{ }^{[1,}, 5 b, 5 c, 6 c, 7\right]$ and triblock ${ }^{[1 \mathrm{c}, 5 \mathrm{~b}]}$ copolymers. However, the chain defects resulting from head-to-head $\left(\mathrm{HH},-\mathrm{CH}_{2} \mathrm{CF}_{2}-\mathrm{CF}_{2} \mathrm{CH}_{2}-\right)$ and tail-totail (TT, $-\mathrm{CF}_{2} \mathrm{CH}_{2}-\mathrm{CH}_{2} \mathrm{CF}_{2^{-}}$) monomer additions impose limits on the molar masses $\left(M_{n}\right)$ and dispersities $(\Theta)$ attainable with these techniques, as demonstrated in both $\operatorname{ITP}^{[5 c]}$ and RAFT ${ }^{[6 \mathrm{c}]}$ polymerization. Upon transfer to the CTA, the $\mathrm{HH}$ additions generate less reactive species that lead to a slowdown of the degenerative chain transfer, a broadening of the molar mass

[a] Dr. S. Banerjee, Dr. V. Ladmiral, Dr. B. Ameduri Ingénierie et Architectures Macromoléculaires, Institut Charles Gerhardt, UMR 5253 CNRS, UM, ENSCM, Place Eugène Bataillon, 34095 Montpellier Cedex 5, France,

E-mail: bruno.ameduri@enscm.fr

\#Present address: Department of Chemistry, Indian Institute of Technology Bhilai, Raipur 492015, Chattisgarh, India

[b] Dr. A. Debuigne, Dr.C. Detrembleur

Center for Education and Research on Macromolecules (CERM) CESAM Research Unit, University of Liege, Department of Chemistry, Sart-Tilman B6a, 4000 Liege, Belgium

[c] Prof. R. Poli, CNRS, LCC (Laboratoire de Chimie de Coordination) and Université de Toulouse, UPS, INPT, 205 route de Narbonne, BP 44099, 31077 Toulouse Cedex 4, France

E-mail: rinaldo.poli@lcc-toulouse.fr

[d] Prof. R. Poli, Institut Universitaire de France, 1, rue Descartes, 75231 Paris Cedex 05, France

Supporting information for this article is given via a link at the end of the document. distribution and a degradation of the control.[6c, 6d, 8] Ideally, a RDRP technique should reactivate both PVDF chain ends at the same rate. Asandei et al. ${ }^{[9]}$ were able to reactivate the $-\mathrm{CF}_{2} \mathrm{CH}_{2}-\mathrm{I}$ terminated PVDF chains and to synthesize block copolymers using $\mathrm{Mn}_{2}(\mathrm{CO})_{10}$ and a photoirradiation process in ITP. However, this was only possible using conventional radical polymerization. Liepins et al. ${ }^{[10]}$ reported the synthesis of PVDF with a low content of $\mathrm{HH}$ chain defects using a modified Ziegler-Natta Catalyst, while Chung's group ${ }^{[11]}$ used a trialkylborane/oxygen mixture as the initiating system, resulting in significant chain defects. However, the controlled nature of these polymerizations was not addressed. In terms of the coordination-insertion strategy for fluorinated alkenes, Jordan et al. ${ }^{[12]}$ described the copolymerization of vinyl fluoride and ethylene using (phosphine-arenesulfonate) $\mathrm{Pd}(\mathrm{Me})(\mathrm{py})$ and phosphinebis (arenesulfonate)PdMe(py) catalysts, while Rieger and coworkers reported the copolymerization of 3,3,3-trifluoropropene with ethylene using (phosphine-sulfonate) $\mathrm{Pd}(\mathrm{Me})(\mathrm{DMSO})$ as catalyst. ${ }^{[13]}$ However, these catalysts did not provide a very good control and, in addition, were not applied to the VDF homopolymerization or VDF-olefin copolymerization

Among other RDRP techniques, organometallic-mediated radical polymerization (OMRP), in which a transition-metal complex reversibly traps the propagating polymer radicals, ${ }^{[14]}$ has been successfully employed for the radical (co)polymerization of less reactive monomers, including vinyl acetate (VAc) ${ }^{[14 a-c]}$ and VAc-ethylene, ${ }^{[15]}$ with $\mathrm{Co}^{11}(\mathrm{acac})_{2}$ (acac $=$ acetylacetonate) as controlling agent. However, there is no report of the application of this technique to homopolymerize fluorinated alkenes. We report here the first OMRP of a fluorinated monomer (VDF) under mild experimental conditions, leading to unprecedented control over the homopolymerization of this monomer (Scheme 1). Furthermore, macromolecular engineering was achieved using the in situ generated PVDF$\mathrm{Co}(\mathrm{acac})_{2}$ macroinitiator to prepare well-defined PVAc and PVDF-containing diblock- and triblock copolymers (Scheme S1).

VDF homopolymerizations were carried out in dimethyl carbonate (DMC, a solvent with a low aptitude to transfer $\mathrm{H}$ atoms to PVDF radicals and which swells $\mathrm{PVDF}^{[1 \mathrm{c}]}$ ) in a Hastelloy (HC 276) autoclave at $40{ }^{\circ} \mathrm{C}$ using [R $(\mathrm{VAC}){ }_{4} \mathrm{Co}^{\mathrm{III}}$ $(\mathrm{acac})_{2}$ as initiator $\left(\mathrm{R}_{0}=\right.$ primary radical generated by $\left.\left.\mathrm{V}-70\right)\right],{ }^{[16]}$ abbreviated as R-Co'"I, at three $[\mathrm{VDF}]_{0} /\left[\mathrm{R}-\mathrm{Co}^{\prime \prime \prime}\right]_{0}$ initial molar ratios (100, 200 and 300). Notably, no polymerization was observed when $\mathrm{V}-70 / \mathrm{Co}$ " (acac) $)_{2}$ was used at $40{ }^{\circ} \mathrm{C}$ or even at $50^{\circ} \mathrm{C}$. This shows that azo initiators are not able to initiate the polymerization of $\mathrm{VDF}^{[13]}$ and justifies the choice of $\mathrm{R}$-Co as initiating species. The selected temperature was the mildest one, allowing to attain a reasonable control. These polymerizations produced PVDFs with higher targeted molar masses $\left(M_{n}=5,900\right.$ to $14,500 \mathrm{~g} / \mathrm{mol})$ and lower dispersities $(\Theta \leq 1.32)$ (P1-P3, Table S1 and Figure S1), than those achieved by ITP or RAFT under the same conditions.

${ }^{1} \mathrm{H},{ }^{19} \mathrm{~F}$ and ${ }^{13} \mathrm{C}$ NMR enabled the structural analysis of the synthesized PVDFs, including the chain ends (see details in $\mathrm{SI}$ ). 
The recovered polymers, isolated after quenching with TEMPO (see SI, Figures S2-S4, P2, Table S1), showed the expected features (normal Head-to-Tail and reversed Head-to-Head and Tail-to-Tail monomer additions) of radically polymerized VDF, the $-\mathrm{CF}_{2} \mathrm{H}$ and $-\mathrm{CH}_{3}$ end-groups originating from transfer reactions to solvent, the characteristic signals of the oligo(VAc) group from the R-Co initiator ( ${ }^{1} \mathrm{H}$ NMR, Figure S2), and the TEMPO chain end $\left({ }^{19} \mathrm{~F}\right.$ NMR, Figure $2 \mathrm{~B}$ and Figure $\left.\mathrm{S} 3\right)$. Notably, only the $\mathrm{R}_{0}-(\mathrm{VAc})_{\sim 4}-\mathrm{CH}_{2} \mathrm{CF}_{2^{-}}$and not the $\mathrm{R}_{0}-(\mathrm{VAc})_{\sim 4}-\mathrm{CF}_{2} \mathrm{CH}_{2}-\alpha-$ chain end could be identified, whereas both $-\mathrm{CF}_{2} \mathrm{CH}_{2}-\mathrm{CH}_{2} \mathrm{CF}_{2-}$ TEMPO and $-\mathrm{CH}_{2} \mathrm{CF}_{2}-\mathrm{CH}_{2} \mathrm{CF}_{2}$-TEMPO $\omega$-chain ends were visible at -66.5 and $-61.5 \mathrm{ppm}$, respectively. The SI offers a more detailed discussion of these assignments.

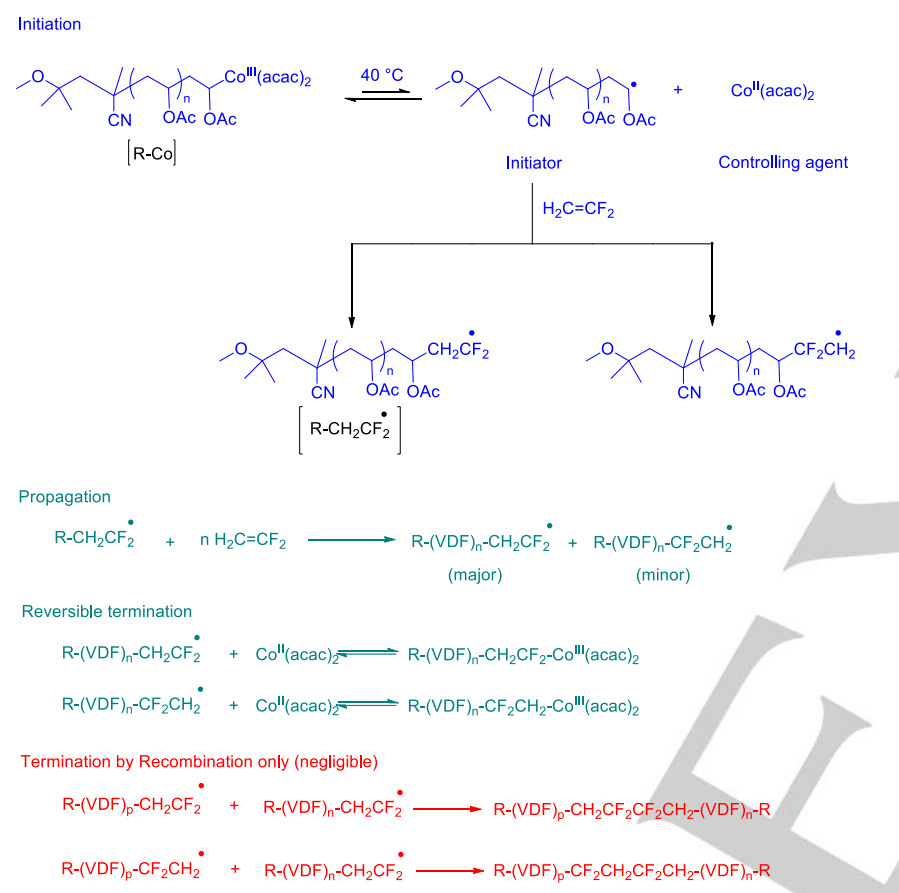

Scheme 1. Mechanism of OMRP of vinylidene fluoride (VDF).

A polymerization kinetic study was carried out through a series of single point experiments (ranging from 0.5 to $24 \mathrm{~h}$, entries 1-7, Table S2), with TEMPO quenching to eliminate the cobalt complex from the polymer chain-end. ${ }^{[17]}$ The VDF conversion was determined gravimetrically, while the $M_{n}$ and $Ð$ values were assessed by SEC calibrated with poly(methyl methacrylate) standards (Table S2). The slope of the "linear" first order kinetic plot (Figure S5B) yields $k_{p(a p p)}=9.6 \times 10^{-6} \mathrm{~s}^{-1}$. This "point by point" kinetic study with seven independent runs demonstrates the reproducibility of the system. The SEC traces (Figure S6) remained narrow and monomodal throughout the polymerization. The $M_{n}$ vs conversion plot (Figure 1) exhibits a monotonous linear increase, maintaining low $\Theta$ values (1.141.29), consistent with the features of RDRP. ${ }^{[5 c]}$

The evolutions of the $-\mathrm{CF}_{2} \mathrm{CH}_{2}$-TEMPO and $-\mathrm{CH}_{2} \mathrm{CF}_{2}$ TEMPO end groups as a function of VDF conversion, monitored by ${ }^{19} \mathrm{~F}$-NMR spectroscopy (Figures S7-S8) are very different from those observed in RAFT[6c] and ITP[18]. The $-\mathrm{CH}_{2} \mathrm{CF}_{2^{-}}$ TEMPO chain end proportion initially decreases, but subsequently stabilizes at $77 \%$ after $20 \%$ conversion.
Meanwhile, the proportions of intrachain $\mathrm{TT}$ and $\mathrm{HH}$ reverse additions (equations S4-S5), which remain close to each other as expected ${ }^{[6 c]}$, increase gradually with VDF conversion (Figure S9), reaching a plateau at ca. $4 \%$. The polymerization pursual at approximately the same rate after stagnation of the terminal $\mathrm{HH}$ and TT inversions demonstrates that both types of dormant chains, PVDF-CH $\mathrm{CF}_{2}-\mathrm{Co}^{\prime \prime \prime}(\mathrm{acac})_{2}$ and PVDF- $\mathrm{CF}_{2} \mathrm{CH}_{2-}$ $\mathrm{Co}^{\text {III }}(\mathrm{acac})_{2}$, are reactivated. Based on this result, we propose that the polymerization proceeds by a typical reversible termination mechanism with $\mathrm{Co}^{\prime \prime}(\mathrm{acac})_{2}$ as the radical trapping species (Scheme 1).

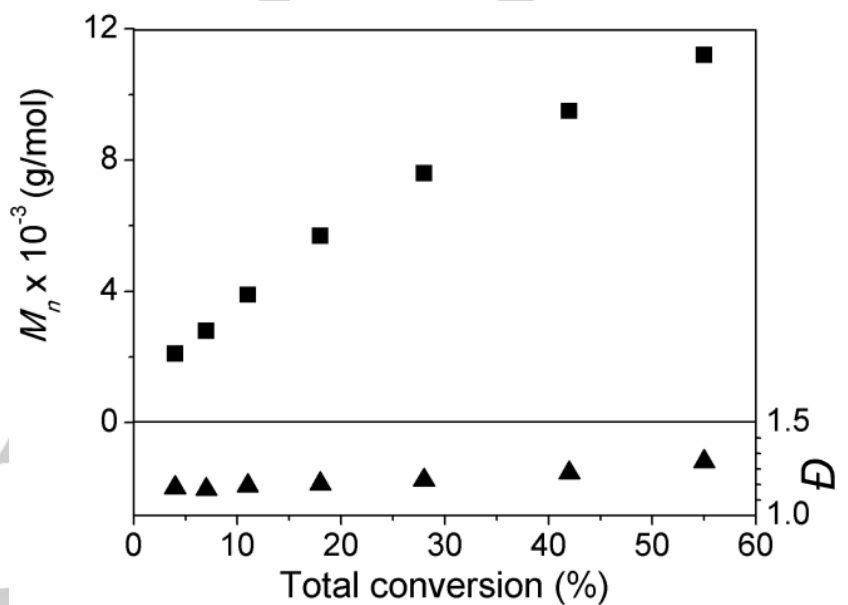

Figure 1. Plots of $M_{n}$ and $\boxminus$ vs conversion for the OMRP of VDF initiated by $\mathrm{R}_{0}(\mathrm{VAc}){ }_{4} \mathrm{Co}(\mathrm{acac})_{2}$ at $40^{\circ} \mathrm{C}$ in DMC (Table S2). [VDF $]_{0} /[\mathrm{R}-\mathrm{Co}]_{0}=200$.

The aptitude of both dormant species to reactivate may be evaluated from the results of a recent DFT study of the Co-C homolytic bond dissociation enthalpies (BDEs) in various $\left(\mathrm{C}_{2} \mathrm{H}_{5-n} \mathrm{~F}_{n}\right) \mathrm{Co}(\mathrm{acac})_{2}$ molecules, with all possible $\mathrm{F}$ substitutions at the $\alpha$ and $\beta$ positions. ${ }^{[19]}$ The $\mathrm{CH}_{3} \mathrm{CF}_{2}-\mathrm{Co}^{\text {III }}(\mathrm{acac})_{2}$ and $\mathrm{CHF}_{2} \mathrm{CH}_{2}-\mathrm{Co}^{\prime \prime \prime}$ (acac) ${ }_{2}$ compounds, which may be considered as models of the head and tail dormant chains, yield $\mathrm{BDE}_{\mathrm{H}}=27.4$ $\mathrm{kcal} / \mathrm{mol}$ and $\mathrm{BDE}_{\mathrm{T}}=26.0 \mathrm{kcal} / \mathrm{mol}$, respectively, ${ }^{[19]}$ for a $\mathrm{BDE}$ difference of $1.4 \mathrm{kcal} / \mathrm{mol}$, which is very small. Even more strikingly, the tail chain-end yields a weaker bond than the head chain-end, predicting an easier reactivation of the tail dormant species. In the case of the $\mathrm{CH}_{3} \mathrm{CF}_{2}-\mathrm{X}$ and $\mathrm{CHF}_{2} \mathrm{CH}_{2}-\mathrm{X}$ models of the 'head' and 'tail' dormant species in ITP $(X=I)$ and RAFT $\{X$ $=\mathrm{SC}(\mathrm{S}) \mathrm{OMe}$, on the other hand, the $\mathrm{BDE}$ is greater for the latter $\left[\triangle \mathrm{BDE}=\mathrm{BDE}_{\mathrm{T}}-\mathrm{BDE}_{\mathrm{H}}=4.2 \mathrm{kcal} / \mathrm{mol}\right.$ for I or $6.2 \mathrm{kcal} / \mathrm{mol}$ for $\mathrm{SC}(\mathrm{S}) \mathrm{OMe}] .{ }^{[8,19]}$ In order to further improve the model, the chain simplification was implemented only at the level of the $\delta \mathrm{C}$ atom. Thus, $\mathrm{PVDF}-\mathrm{CF}_{2} \mathrm{CH}_{2}-\mathrm{Co}^{\prime \prime \prime}(\mathrm{acac})_{2}$ was modeled by $\mathrm{CHF}_{2} \mathrm{CF}_{2} \mathrm{CH}_{2}-\mathrm{Co}^{\text {III }}(\mathrm{acac})_{2}$, for which the calculated $\mathrm{BDE}$ is 25.2 $\mathrm{kcal} / \mathrm{mol}$, and PVDF-CH $\mathrm{CF}_{2}-\mathrm{Co}^{\prime \prime \prime}(\mathrm{acac})_{2}$ was modeled by

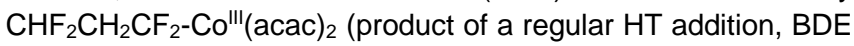
$=27.9 \mathrm{kcal} / \mathrm{mol}$ ) and $\mathrm{CH}_{3} \mathrm{CH}_{2} \mathrm{CF}_{2}-\mathrm{Co}^{\prime \prime \prime}(\mathrm{acac})_{2}$ (product of a TT addition, $\mathrm{BDE}=27.4 \mathrm{kcal} / \mathrm{mol})$. The computational details are given in the SI. Qualitatively, the bond strengths remain in the order $\mathrm{PVDF}_{\mathrm{T}-\mathrm{Co}^{\prime \prime \prime}}(\mathrm{acac})_{2}<\mathrm{PVDF}_{\mathrm{H}}-\mathrm{Co}^{\prime \prime \prime}(\mathrm{acac})_{2}$, predicting no accumulation of the $\mathrm{PVDF}_{\mathrm{T}}-\mathrm{Co}^{\prime \prime \prime}(\mathrm{acac})_{2}$ in the medium (contrary to RAFT and ITP). In reality, the observation of a greater proportion of $\mathrm{PVDF}_{\mathrm{T}}-\mathrm{Co}^{\prime \prime \prime}(\mathrm{acac})_{2}$ dormant chains (Figure S8) 
relative to the in-chain errors means that the experimental bond strengths must be in the opposite order $\left(\mathrm{PVDF}_{\mathrm{T}}-\mathrm{Co}^{\prime \prime \prime}(\mathrm{acac})_{2}>\right.$ $\left.\mathrm{PVDF}_{\mathrm{H}^{-}} \mathrm{Co}^{\prime \prime \prime}(\mathrm{acac})_{2}\right)$, but the difference must be much smaller than in the corresponding ITP and RAFT dormant species.
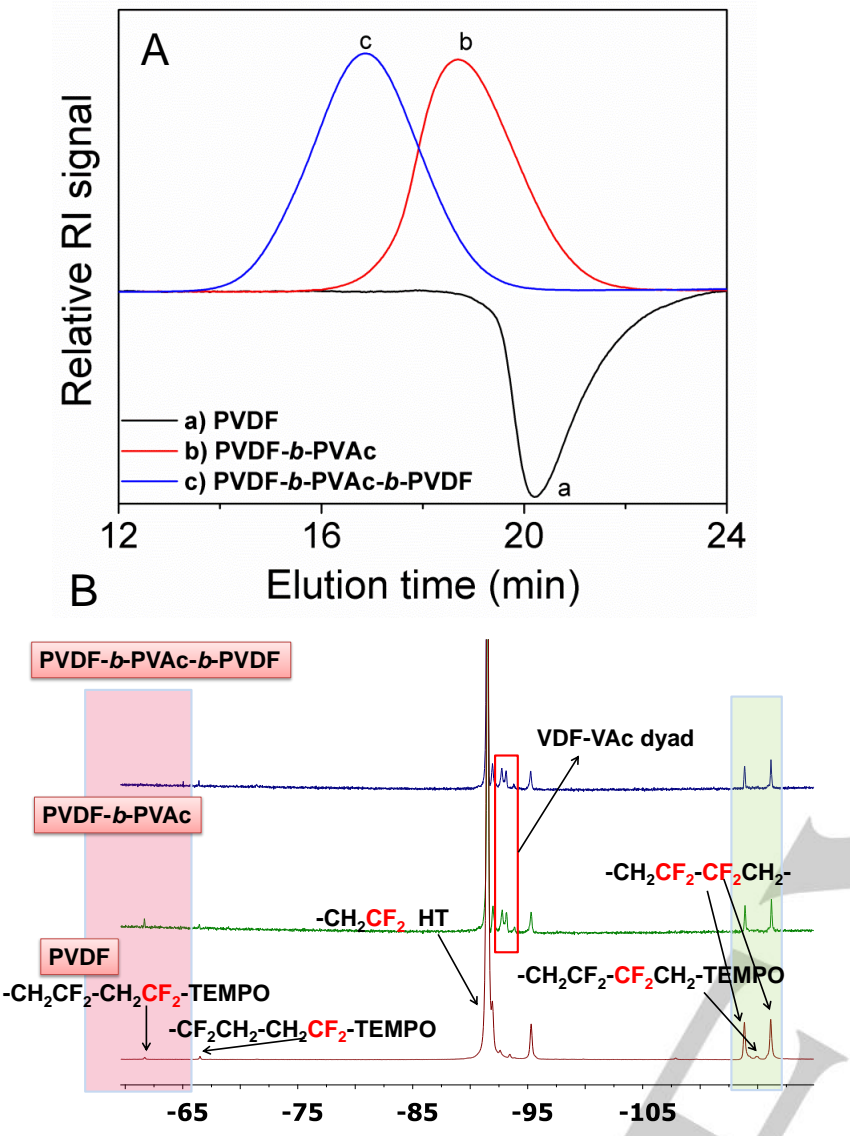

Figure 2. A) SEC traces of the PVDF prepared by $\mathrm{Co}$ (acac)2-mediated OMRP (trace a, after $24 \mathrm{~h}$ ), of the PVDF-b-PVAc diblock copolymer (trace b, after $24+24 h$ ) obtained by chain extension with VAc, and of the PVDF- $b-P V A c-b-$ PVDF triblock copolymer (trace c, after $24+24+16 \mathrm{~h}$ ) prepared by chain coupling of the previous diblock copolymer using isoprene. B) ${ }^{19} \mathrm{~F} N M R$ spectra of PVDF (bottom), of the PVDF- $b$-PVAc diblock copolymer (middle), and of the PVDF- $b$-PVAc- $b$-PVDF triblock copolymer (top).

In addition to improved control in VDF homopolymerization, the labile carbon-metal bond in PVDF-Co'll(acac) $)_{2}$ allowed reactivation for chain extension with VAc, leading to PVDF- $b$ PVAc diblock copolymers and increasing the scope of available PVDF-containing block copolymers. ${ }^{[6 \mathrm{~d}, 20]}$ The SEC chromatograms (Figure 2A) show a shift of the PVDF-Co'II(acac) distribution (trace $a, M_{n}=4,100 \mathrm{~g} / \mathrm{mol}, \ominus=1.27$ ) toward higher molar masses upon chain extension to form the PVDF- $b$-PVAc diblock, while maintaining low $\Theta$ values (trace $b, M_{n}=10,300$ $\mathrm{g} / \mathrm{mol}, \oplus=1.28$ ). As expected, the RI-SEC chromatograms of the PVDFs were negative (fluoropolymers have low refractive index). $\left.{ }^{[16,6 b}, 21\right]{ }^{1} \mathrm{H}$ and ${ }^{19} \mathrm{~F}$ NMR spectra (Figures $\mathrm{S} 10$ and $2 \mathrm{~B}$, respectively) show the characteristic $\mathrm{PVAc}-\mathrm{CH}(\mathrm{OAc})$ - signal at $4.8 \mathrm{ppm}$ and the VDF-VAc dyad $-\mathrm{CF}_{2}-$ signal at $-93.3 \mathrm{ppm}$, confirming the product structure. ${ }^{[6 \mathrm{~d}]}$

$\mathrm{Co}^{\prime \prime \prime}(\mathrm{acac})_{2}$-terminated polymers prepared by OMRP are known to undergo rapid chain-chain coupling upon addition of a conjugated diene, affording double-molecular weight terminated products $^{[22]}$ and allowing the facile synthesis of symmetric ABA triblock copolymers when starting from Co $\mathrm{Co}^{\text {III }}(\mathrm{acac})_{2}$-terminated AB diblock copolymers. ${ }^{[22]}$ Application of this technique to PVDF$b$-PVAc-Co'II(acac) ${ }_{2}$ using isoprene as coupling agent yielded a symmetrical PVDF- $b$-PVAc- $b$-PVDF triblock copolymer (Scheme S1). The SEC chromatograms revealed that the $M_{n}$ of the coupled product approximately doubled $(19,900 \mathrm{~g} / \mathrm{mol}$ vs 10,300 $\mathrm{g} / \mathrm{mol}$ ) while the dispersity remained low (Table S3).

As expected, the thermal stability of the produced PVDFs increases with increasing $M_{n}$ (P1-P3, Table S1), as shown by the thermogravimetric analyses (TGA) (Figure S11). The melting points $\left(T_{m}\right)$ of these samples, determined by differential scanning calorimetry, were similar (ca. $163{ }^{\circ} \mathrm{C}$ ) (Figure S12). Expectedly, the degree of crystallinity increased from 34 to $54 \%$ (calculated using equation S3) with increasing $M_{n}$.

The thermal stabilities (TGA, Figure S13) of the PVAccontaining di-/tri-block copolymers were close to those of the PVDF homopolymers as evidenced by their $T_{d, 10 \%}$ decomposition temperatures (Table S3). However, the di-and triblock copolymer displayed a $T_{g}$ characteristic of the PVAc block (at ca. $\left.35^{\circ} \mathrm{C}\right)^{[23]}$ and a reduced degree of crystallinity ( $\left.\leq 8 \%\right)$ relative to neat PVDF (Table S3, Figures S15-S16).

In conclusion, this communication reports the first example of an organometallic-mediated radical polymerization (OMRP) of VDF and demonstrates an unprecedented level of control for this monomer, including the first synthesis of a block copolymer with successful transition to a second RDRP process. This was possible thanks to the facile reactivation of the dormant species formed after an inverted monomer addition, $\mathrm{PVDF}_{\mathrm{T}} \mathrm{X}$, when $\mathrm{X}=$ $\mathrm{Co}^{\prime \prime \prime}(\mathrm{acac})_{2}$, whereas the reactivation of these chains is inefficient in ITP $(X=I)$ and RAFT (X = xanthate). Due to the remarkable properties of the fluorinated groups (low dielectric constant and interesting thermal, electroactive and surface properties), the resulting copolymers might find applications in high value added materials (e.g., coatings, binders for lithium ion batteries, piezoelectric devices, and membranes).

\section{Acknowledgements}

Financial support from the French national agency (ANR grant FLUPOL) is greatly appreciated. C.D. and A.D. are Research Director and Research Associate by FNRS, respectively, and thank FNRS for financial support. This work was granted access to the HPC resources of CINES and IDRIS under the allocation (2006-2017)-086343 made by GENCI (Grand Equipement National de Calcul Intensif) and to the resources of the CICT (Centre Interuniversitaire de Calcul de Toulouse, project CALMIP).

Keywords: alkyl cobalt species • block copolymer • organometallic mediated radical polymerization $\bullet$ one pot synthesis • vinylidene fluoride

[1] a) B. Améduri, Chem. Rev. 2009, 109,6632-6686; b) D. W. Smith, S. T. lacono, S. S. Iyer, Handbook of Fluoropolymer Science and Technology, 
Wiley, New York, 2014; c) A. D. Asandei, Chem. Rev. 2016, 116, 2244 2274; d) B. Améduri, H. Sawada, Fluorinated Polymers: From Fundamental to Practical Synthesis and Applications. Volume 1: Synthesis, Properties, Processing and Simulations, Royal Society of Chemistry, Oxford, 2016.

[2] L. Yang, X. Li, E. Allahyarov, P. L. Taylor, Q. M. Zhang, L. Zhu, Polymer 2013, 54, 1709-1728.

[3] Z. Cui, E. Drioli, Y. M. Lee, Prog. Polym. Sci. 2013, 39, 164-198.

[4] F. Boschet, B. Améduri, Chem. Rev. 2014, 114, 927-980.

[5] a) M. Tatemoto, in The first Regular Meeting of Soviet-Japanese Fluorine Chemists, Tokyo, 1979; b) M. Tatemoto, Vol. 5 (Ed.: J. C. Salamone), CRC Boca Raton, 1996, pp. 3847-3862; c) G. David, C. Boyer, J. Tonnar, B. Améduri, P. Lacroix-Desmazes, B. Boutevin, Chem. Rev. 2006, 106 3936-3962; d) R. Vukicevic, U. Schwadtke, S. Schmucker, P. Schafer, D. Kuckling, S. Beuermann, Polym. Chem. 2012, 3, 409-414.

[6] a) G. Kostov, F. Boschet, J. Buller, L. Badache, S. Brandsadter, B. Améduri, Macromolecules 2011, 44, 1841-1855; b) E. Girard, J. D. Marty, B. Améduri, M. Destarac, ACS Macro Lett. 2012, 1, 270-274; c) M. Guerre B. Campagne, O. Gimello, K. Parra, B. Ameduri, V. Ladmiral, Macromolecules 2015, 48, 7810-7822; d) M. Guerre, S. M. W. Rahaman B. Améduri, R. Poli, V. Ladmiral, Polym. Chem. 2016, 6918-6933.

[7] E. Girard, J.-D. Marty, B. Ameduri, M. Destarac, ACS Macro Lett. 2012, 1, 270-274.

[8] M. Guerre, S. M. W. Rahaman, B. Améduri, R. Poli, V. Ladmiral, Macromolecules 2016, 49, 5386-5396.

[9] A. D. Asandei, O. I. Adebolu, C. P. Simpson, J. Am. Chem. Soc. 2012, 134, 6080-6083.

[10] R. Liepins, J. R. Surles, N. Morosoff, V. T. Stannett, M. L. Timmons, J. J. Wortman, J. Polym. Sci. Part A: Polym. Chem. 1978, 16, 3039-3044.

[11] Z. C. Zhang, Z. M. Wang, T. C. M. Chung, Macromolecules 2007, 40, 5235-5240.

[12] a) W. Weng, Z. Shen, R. F. Jordan, J. Am. Chem. Soc. 2007, 129, 1545015451; b) Z. Shen, R. F. Jordan, Macromolecules 2010, 43, 8706-8708 C) S. Wada, R. F. Jordan, Angew. Chem. Int. Ed. 2017, 56, 1820 -1824.

[13] D. Lanzinger, M. M. Giuman, T. M. J. Anselment, B. Rieger, ACS Macro Letters 2014, 3, 931-934.

[14] a) R. Poli, Angew. Chem. Int. Ed. 2006, 45, 5058-5070; b) A. Debuigne, M. Hurtgen, C. Detrembleur, C. Jerome, C. Barner-Kowollik, T. Junkers, Prog. Polym. Sci. 2012, 37, 1004-1030; c) L. E. N. Allan, M. R. Perry, M. P. Shaver, Progr. Polym. Sci. 2012, 37, 127-156; d) A. Debuigne, C. Jerome, C. Detrembleur, Polymer 2017, 115, 285-307.

[15] A. Kermagoret, A. Debuigne, C. Jerome, C. Detrembleur, Nat. Chem. 2014, 6, 179-187.

[16] A. Debuigne, Y. Champouret, R. Jérôme, R. Poli, C. Detrembleur, Chem. Eur. J. 2008, 14, 4046-4059.

[17] A. Debuigne, J.-R. Caille, R. Jérôme, Macromolecules 2005, 38, 5452 5458.

[18] S. Banerjee, Y. Patil, T. Ono, B. Améduri, Macromolecules 2017, 50, 203 214.

[19] R. Poli, S. M. W. Rahaman, V. Ladmiral, B. Améduri, J. Organomet. Chem. 2018, DOI: 10.1016/j.jorganchem.2017.1012.1020.

[20] a) V. S. D. Voet, G. ten Brinke, K. Loos, J . Polym. Sci. Part A: Polym Chem. 2014, 52, 2861-2877; b) M. Guerre, M. Uchiyama, E. Folgado, M. Semsarilar, B. Améduri, K. Satoh, M. Kamigaito, V. Ladmiral, ACS Macro Lett. 2017, 6, 393-398; c) M. Guerre, J. Schmidt, Y. Talmon, B. Améduri, V. Ladmiral, Polym. Chem. 2017, 8, 1125-1128; d) M. Guerre, M Semsarilar, F. Godiard, B. Ameduri, V. Ladmiral, Polym. Chem. 2017, 8 1477-1487; e) M. Guerre, M. Semsarilar, C. Totee, G. Silly, B. Améduri, V. Ladmiral, Polym. Chem. 2017, 8, 5203-5211.

[21] M. Destarac, K. Matyjaszewski, E. Silverman, B. Améduri, B. Boutevin, Macromolecules 2000, 33, 4613-4615.

[22]A. Debuigne, C. Jerome, C. Detrembleur, Angew. Chem. Int. Ed. 2009, 48 , 1422-1424.

[23] J. Ahmad, M. B. Hågg, J. Membrane Sci. 2013, 445, 200-210. 


\section{Entry for the Table of Contents}

\section{COMMUNICATION}

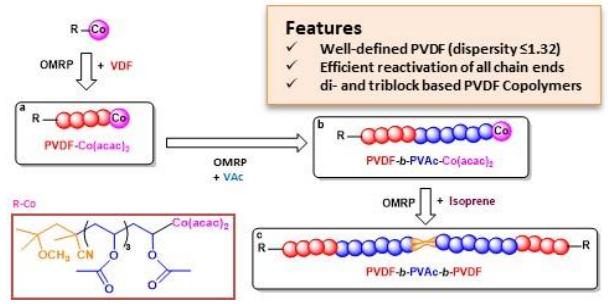

Sanjib Banerjee, Vincent Ladmiral, Antoine Debuigne, Christophe Detrembleur, Rinaldo Poli* and Bruno Ameduri*

Organometallic Mediated Radical Polymerization of Vinylidene Fluoride

Towards new possibilities: An unprecedented organometallic mediated radical polymerization (OMRP) of VDF yielded well-defined PVDF (at least up to 14,500 $\mathrm{g} / \mathrm{mol}$ ) with low dispersity ( $\leq 1.32)$. The experimental findings show that both head and chain ends exhibits reactivation and these experimental findings are supported by DFT calculations. 